\title{
The Dick Test in relation to the presence of the Streptococcus Haemolyticus in the Throats of Individuals not suffering from Scarlet Fever
}

BY

\author{
J. SMITH, M.D., D.P.H.
}

\author{
From the City Hospital Laboratory, Aberdeen.
}

It is generally held by most authorities that when the throat of a Schickpositive reactor becomes infected with a strain of virulent $C$. diphthcrice, the individual will almost certainly develop clinical diphtheria within a few days, and that when a Schick-positive reactor is found to be a carrier then the diphtheria organism is non-virulent.

It was resolved, therefore, to ascertain whether $S$. hsmolyticus could be found in the throat cultures of those who were Dick positive, and further to determine whether the various strains could be separated into scarlatinal and non-scarlatinal types. As it has already been shown (Smith, 1926, 1927, Griffith, 1926, James, 1926) that scarlatinal types cannot be distinguished by agglutination and agglutinin-absorption tests from strains of hæmolytic streptococci occurring in other infections, the various strains were tested for their power to produce a true exotoxin, and tests were made to determine if the exotoxins were neutralised by scarlatinal horse-antitoxin.

\section{METHODS.}

The Dick test was applied in the first instance to seven nurses and thirteen patients in a scarlet infected children's ward, and secondly to forty patients convalescing from diphtheria, and at the same time swabs were ubtained of the secretions of the throat. These secretions were emulsified in broth, and blood agar plates were inoculated and incubated overnight. Typical colonies were selected and replated. After an incubation period of twenty-four hours colonies were picked into tubes containing blood broth and incubated. The hæmolytic activity of each strain was tested by growing in twenty per cent. horse serum broth medium, and after an incubation period of eight hours $0 \cdot 1$ c.c. of the culture fluid was added to 1 c.c. of two per cent. washed sheep's red blood cells, and this mixture was incubated in a water bath at $37^{\circ} \mathrm{C}$. for one hour. The various strains were also tested for their resistance to bile, and for their action in media containing the carbohydrates, lactose, salicin, mannite, inulin, and raffinose. The serological classification of these various strains was accomplished by methods already described (Smith, 1926, 1927).

For the production of toxin, flasks containing 50 c.c. quantities of Hartley's trypsin-broth were inoculated with the various strains. After an incubation 
period of forty-eight hours 0.4 per cent. phenol was added to the cultures, which were then centrifuged. The supernatant fluids were passed through sterilised L2 Chamberland candle filters and the filtrates were stored in the refrigerator until required.

In order to test whether a filtrate contained a true exotoxin six intracutaneous tests (three on the flexor aspect of both arms) were made on a series of individuals with 0.2 c.c. of the following fluids :-

1. Dick test toxin $=1$ skin test dose.

2. Dick test control.

3. Toxin from strain under examination diluted 1 in 100 .

4. Toxin from strain under examination diluted to 1 in 100 and boiled for four hours-control for test No. 3 .

5. Toxin from strain under examination diluted to 1 in 100 with a concentrated horse scarlet fever antitoxin diluted 1 in 10. (This mixture was incubated in the water bath for one hour at $37^{\circ} \mathrm{C}$. just prior to inoculation.)

6. Horse scarlet fever antitoxin diluted 1 in 10 -control for test No. 5 .

The scarlet fever antitoxin used in the neutralization test was certified as being capable of neutralising 50,000 skin test doses of toxin per c.c. so that 1 c.c. diluted 1 in 10 with salt solution would be capable of neutralizing 5,000 skin test doses of toxin.

Owing to the presence of horse serum in the neutralisation test mixtures a considerable number of 'pseudo' reactions appeared and these made the interpretation of skin tests difficult. All reactions which were complicated by the 'pseudo' factor, whether due to horse serum or due to protein in the toxin filtrate, were discarded, and only the clear cut results obtained twenty-four hours after making the tests have been recorded in the following pages. The reactions produced by the toxins are recorded as being,,++++++ , ++++ , and negative.

\section{Results.}

In a series of sixty cases twenty-seven gave a positive Dick test, and twenty-three a negative test. The relationship of the Dick tests to those harbouring $S$. huemolyticus is given in Table I from which it will be seen that while eight cases harbouring $S$. homolyticus gave a negative Dick test, six cases gave a comparatively feeble positive reaction varying between one + and two ++ . The serological classification showed that one Type I, two Type II, two Type $X$, and one unclassified strain were obtained from the Dick-negative reactors, and that one Type II, one Type III, one Type IV, two Type $\mathrm{X}$ and one unclassified strain were obtained from Dick-positive patients. In previous papers it has been shown that strains with the same serological characteristics were obtained from the throats of acute cases of scarlet fever. 
TABLE I.

Cases Showing S. Hamolyticus.

\begin{tabular}{|c|c|c|c|c|c|c|}
\hline \multirow{2}{*}{$\begin{array}{l}\text { Case } \\
\text { No. }\end{array}$} & \multirow{2}{*}{ Age. } & \multicolumn{2}{|c|}{ Dick Test. } & \multirow{2}{*}{$\begin{array}{c}\text { Culture } \\
\text { from } \\
\text { Throat. }\end{array}$} & \multirow{2}{*}{$\begin{array}{c}\text { Serological } \\
\text { Type. }\end{array}$} & \multirow{2}{*}{$\begin{array}{c}\text { Strain } \\
\text { No. }\end{array}$} \\
\hline & & Test. & Control. & & & \\
\hline 2 & 22 & 0 & 0 & + & I & 1 \\
\hline 4 & 22 & 0 & 0 & + & $\mathrm{X}$ & 2 \\
\hline 11 & 21 & 0 & 0 & + & II & 3 \\
\hline 18 & $4 / 12$ & 0 & 0 & + & II & 4 \\
\hline 19 & $13 / 12$ & ++ & 0 & + & II & 5 \\
\hline 20 & $5 / 12$ & 0 & 0 & + & II & 6 \\
\hline 23 & 14 & 0 & 0 & + & $\mathrm{X}$ & 7 \\
\hline 25 & 3 & + & 0 & + & $\mathrm{X}$ & 8 \\
\hline 35 & 5 & ++ & 0 & + & IV & 9 \\
\hline 37 & 13 & + & 0 & + & Unclassified & 10 \\
\hline 39 & 5 & 0 & 0 & + & Unclassified & 11 \\
\hline 47 & 19 & + & 0 & + & $\mathrm{X}$ & 12 \\
\hline 57 & 39 & + & 0 & + & III & 13 \\
\hline 58 & 22 & 0 & 0 & + & $\mathrm{X}$ & 14 \\
\hline
\end{tabular}

The results obtained on testing the filtrates for toxicity and for neutralisation with antitoxin are summarised in Table II. It was found, therefore, that all strains produced filtrates capable of giving reactions in human beings similar to the Dick test toxin. It was found, also, that the substance producing the reaction was destroyed by boiling for four hours and was neutralised by horse scarlet antitoxin. The majority of the strains produced a filtrate which, when used in a dilution of 1 in 100 , caused many more positive reactions than the Dick test toxin. This was due to the fact that $0 \cdot 2$ c.c. of 1 in 100 dilution of a filtrate probably contained five to ten skin test doess instead of one skin test dose, and it can be shown that many more individuals react to five or ten skin test doses than to one skin test dose. So far as these tests go, there is nothing to indicate that the various toxins differ in constitution from the Dick test toxin, despite the fact that the toxins were obtained from strains belonging to five serological types and from two unclassified strains.

It has been established, therefore, that certain individuals, who are Dick negative or who give slight Dick-positive reactions, can be carriers of hæmolytic streptococci capable of producing a true exotoxin which can be neutralised by a horse scarlet fever antitoxin. This may indicate that those individuals who give feeble positive Dick tests and who harbour hæmolytic 
TABLE II.

Dick Tests and Tests with Filtrates from Strains.

\begin{tabular}{|c|c|c|c|c|c|c|c|c|}
\hline \multirow[t]{2}{*}{ Series. } & \multirow{2}{*}{$\begin{array}{l}\text { Case } \\
\text { No. }\end{array}$} & \multicolumn{2}{|c|}{ Dick Test. } & \multirow{2}{*}{$\begin{array}{l}\text { Filtrate } \\
\text { from } \\
\text { Strain. }\end{array}$} & \multicolumn{2}{|c|}{ Filtrate Test. } & \multicolumn{2}{|c|}{$\begin{array}{c}\text { Neutralisation } \\
\text { Test. }\end{array}$} \\
\hline & & Test. & Control. & & Test. & Control. & Test. & Control. \\
\hline 1 & $\begin{array}{l}1 \\
2 \\
3\end{array}$ & $\begin{array}{l}t+ \\
+t+ \\
t+\end{array}$ & $\begin{array}{l}0 \\
0 \\
0\end{array}$ & 1 & $\begin{array}{l}++++ \\
++++ \\
++t\end{array}$ & $\begin{array}{l}0 \\
0 \\
0\end{array}$ & $\begin{array}{l}0 \\
0 \\
0\end{array}$ & $\begin{array}{l}0 \\
0 \\
0\end{array}$ \\
\hline 2 & $\begin{array}{l}1 \\
2 \\
3 \\
4\end{array}$ & $\begin{array}{c}++t+ \\
++0 \\
0\end{array}$ & $\begin{array}{l}0 \\
0 \\
0 \\
0\end{array}$ & 2 & $\begin{array}{l}+t-t+ \\
+- \\
++-1-t \\
t+\end{array}$ & $\begin{array}{l}0 \\
0 \\
0 \\
0\end{array}$ & $\begin{array}{l}0 \\
0 \\
0 \\
0\end{array}$ & $\begin{array}{l}0 \\
0 \\
0 \\
0\end{array}$ \\
\hline 3 & $\begin{array}{l}1 \\
2 \\
3 \\
4\end{array}$ & $\begin{array}{c}+t+t \\
++ \\
0 \\
0\end{array}$ & $\begin{array}{l}0 \\
0 \\
0 \\
0\end{array}$ & 3 & $\begin{array}{l}+++t \\
+++t \\
++t \\
++t\end{array}$ & $\begin{array}{l}0 \\
0 \\
0 \\
0\end{array}$ & $\begin{array}{l}0 \\
0 \\
0 \\
0\end{array}$ & $\begin{array}{l}0 \\
0 \\
0 \\
0\end{array}$ \\
\hline 4 & $\begin{array}{l}1 \\
2 \\
3 \\
4\end{array}$ & $\begin{array}{c}0 \\
0 \\
++ \\
++++\end{array}$ & $\begin{array}{l}0 \\
0 \\
0 \\
0\end{array}$ & 4 & $\begin{array}{l}+++ \\
+++ \\
+++ \\
++++\end{array}$ & $\begin{array}{l}0 \\
0 \\
0 \\
0\end{array}$ & $\begin{array}{l}0 \\
0 \\
0 \\
0\end{array}$ & $\begin{array}{l}0 \\
0 \\
0 \\
0\end{array}$ \\
\hline 5 & $\begin{array}{l}1 \\
2 \\
3\end{array}$ & $\begin{array}{c}+t+ \\
0 \\
++t\end{array}$ & $\begin{array}{l}0 \\
0 \\
0\end{array}$ & 5 & $\begin{array}{l}++t+ \\
+t \\
++t\end{array}$ & $\begin{array}{l}0 \\
0 \\
0\end{array}$ & $\begin{array}{l}0 \\
0 \\
0\end{array}$ & $\begin{array}{l}0 \\
0 \\
0\end{array}$ \\
\hline 6 & $\begin{array}{l}1 \\
2 \\
3 \\
4\end{array}$ & $\begin{array}{c}0 \\
++t \\
0 \\
++t+\end{array}$ & $\begin{array}{l}0 \\
0 \\
0 \\
0\end{array}$ & 6 & $\begin{array}{l}++ \\
++t+ \\
+++ \\
++t-1\end{array}$ & $\begin{array}{l}0 \\
0 \\
0 \\
0\end{array}$ & $\begin{array}{l}0 \\
0 \\
0 \\
0\end{array}$ & $\begin{array}{r}-0 \\
0 \\
0 \\
0 \\
\end{array}$ \\
\hline 7 & $\begin{array}{l}1 \\
2 \\
3 \\
4\end{array}$ & $\begin{array}{c}+t+ \\
+t+ \\
++\end{array}$ & $\begin{array}{l}0 \\
0 \\
0 \\
0\end{array}$ & 7 & $\begin{array}{l}+++ \\
+++ \\
++ \\
0\end{array}$ & $\begin{array}{l}0 \\
0 \\
0 \\
0\end{array}$ & $\begin{array}{l}0 \\
0 \\
0 \\
0\end{array}$ & $\begin{array}{l}0 \\
0 \\
0 \\
0\end{array}$ \\
\hline 8 & $\begin{array}{l}1 \\
2 \\
3 \\
4\end{array}$ & $\begin{array}{c}++t+1 \\
0 \\
0 \\
0\end{array}$ & $\begin{array}{l}0 \\
0 \\
0 \\
0\end{array}$ & 8 & $\begin{array}{l}+++t \\
++ \\
+{ }_{0}\end{array}$ & $\begin{array}{l}0 \\
0 \\
0 \\
0\end{array}$ & $\begin{array}{l}0 \\
0 \\
0 \\
0\end{array}$ & $\begin{array}{l}0 \\
0 \\
0 \\
0\end{array}$ \\
\hline 9 & $\begin{array}{l}1 \\
2 \\
3 \\
4\end{array}$ & $\begin{array}{r}0 \\
0 \\
++ \\
+-t\end{array}$ & $\begin{array}{l}0 \\
0 \\
0 \\
0\end{array}$ & 9 & $\begin{array}{c}0 \\
+ \\
++t \\
++t\end{array}$ & $\begin{array}{l}0 \\
0 \\
0 \\
0\end{array}$ & $\begin{array}{l}0 \\
0 \\
0 \\
0\end{array}$ & $\begin{array}{l}0 \\
0 \\
0 \\
0\end{array}$ \\
\hline 10 & $\begin{array}{l}1 \\
2 \\
3 \\
4\end{array}$ & $\begin{array}{l}t+-t \\
t+t \\
t+ \\
0\end{array}$ & $\begin{array}{l}0 \\
0 \\
0 \\
0\end{array}$ & 10 & $\begin{array}{l}++t+ \\
++t \\
+t \\
+\end{array}$ & $\begin{array}{l}0 \\
0 \\
0 \\
0\end{array}$ & $\begin{array}{l}0 \\
0 \\
0 \\
0\end{array}$ & $\begin{array}{l}0 \\
0 \\
0 \\
0\end{array}$ \\
\hline 11 & $\begin{array}{l}1 \\
2 \\
3 \\
4\end{array}$ & $\begin{array}{l}0 \\
0 \\
0 \\
0\end{array}$ & $\begin{array}{l}0 \\
0 \\
0 \\
0\end{array}$ & 11 & $\begin{array}{l}+t+ \\
++ \\
-t+ \\
+t\end{array}$ & $\begin{array}{l}0 \\
0 \\
0 \\
0\end{array}$ & $\begin{array}{l}0 \\
0 \\
0 \\
0\end{array}$ & $\begin{array}{l}0 \\
0 \\
0 \\
0\end{array}$ \\
\hline 12 & $\begin{array}{l}1 \\
2 \\
3\end{array}$ & $\begin{array}{l}t-t \\
0 \\
+t\end{array}$ & $\begin{array}{l}0 \\
0 \\
0\end{array}$ & 12 & $\begin{array}{l}+-++t \\
+++ \\
+++-!\end{array}$ & $\begin{array}{l}0 \\
0 \\
0\end{array}$ & $\begin{array}{l}0 \\
0 \\
0\end{array}$ & $\begin{array}{l}0 \\
0 \\
0\end{array}$ \\
\hline 13 & $\begin{array}{l}1 \\
2 \\
3 \\
4\end{array}$ & $\begin{array}{r}0 \\
0 \\
++\quad 0\end{array}$ & $\begin{array}{l}0 \\
0 \\
0 \\
0\end{array}$ & 13 & $\begin{array}{l}0 \\
+-t \\
+++ \\
+\end{array}$ & $\begin{array}{l}0 \\
0 \\
0 \\
0\end{array}$ & $\begin{array}{l}0 \\
0 \\
0 \\
0\end{array}$ & $\begin{array}{l}0 \\
0 \\
0 \\
0\end{array}$ \\
\hline 14 & $\begin{array}{l}1 \\
2 \\
3\end{array}$ & $\begin{array}{r}0 \\
0 \\
+++ \\
+\end{array}$ & $\begin{array}{l}0 \\
0 \\
0 \\
11\end{array}$ & 14 & $\begin{array}{l}0 \\
++ \\
++t \\
+\end{array}$ & $\begin{array}{l}0 \\
0 \\
0 \\
0\end{array}$ & $\begin{array}{l}0 \\
0 \\
0 \\
0\end{array}$ & $\begin{array}{l}0 \\
0 \\
0 \\
0\end{array}$ \\
\hline
\end{tabular}


streptococci are really immune to scarlet fever, or that they are protected by a local immunity mechanism. In the case of the Schick test an accurate method of measuring the toxin has been devised and further, it has been definitely ascertained that $\frac{1}{30}$ to $\frac{1}{50}$ of a unit of antitoxin per c.c of human serum is required to give protection against diphtheria. The toxin used at present for the Dick test may therefore require further standardisation in order to make the Dick test results comparable to those obtained with the Schick test. Meantime scarlatinal and non-scarlatinal types of hæmolytic streptococci, if such exist, cannot be distinguished by the methods described above.

REFERENCES.

1. Griffith, F., 1916 : Jour. Hygiene, Camb., XXV, 385.

2. James, G. R., 1926 : Ibid. XXV, 415.

3. Smith, J., 1926 : Ibid. XXV, 165.

4. Smith, J., 1927 : Ibid. (In the press.) 